\title{
Learning Tasks Design in Improving Reading Comprehension Ability of Informational Text of 5th Grade in Indonesia: An Interactive- compensatory Model Use
}

\author{
Tri Indri Hardini \\ Universitas Pendidikan Indonesia, Indonesia \\ Ryan Dwi Puspita \\ STKIP Sebelas April, Indonesia \\ Rully Agung Yudhiantara \\ UIN Sunan Gunung Djati, Indonesia
}

\begin{abstract}
In Indonesian context, based on the observation, 5th grade elementary school students in Bandung Regency had low reading comprehension ability for informational text. This can be seen from their low ability to express explicit meanings, define the main idea, search for keywords and retell the contents of the text with their own words. Given this circumstance, it is necessary to improve task design using particular learning models to improve students' reading comprehension ability. Therefore this study was aimed at investigating the effect of the use of task design based on Interactive-Compensatory model to improve reading comprehension of 5th grade. The study used quasi experimental method. It applied observation, pre-test, posttest and interview to collect data. There were 136 samples of 5th grade participating in this study. The findings showed that there was a significant influence since there was a difference in sudents' reading comprehension ability to read informational text before and after they were treated using task design based on the InteractiveCompensatory model.
\end{abstract}

Index Terms-Elementary School, Interactive-compensatory Model, reading comprehension, task design, 5th grade

\section{INTRODUCTION}

This study has similar scope with the previous study conducted by the authors because the studies focus on an effort to improve 5th grade of elementary school reading comprehension ability. The previous study found that, especially in Bandung regency, the 5th graders had difficulty in reading comprehension ability for informational text (RCAIT). It found that students had low RCAIT because they had poor competence to understand explicit meanings, understand important information, apply information, analyze information, evaluate information that they had understood. They had a problem in observing, listening, seeing, reading and questioning based on critical curiosity about himself, God's creatures, activities and the objects they encountered in homes, schools, and playgrounds using clear, logical and systematic language (Puspita, et.all., 2017). On the other hand, national standard curriculum (NSC) for 5th grade elementary school of reading comprehension ability states that students must be able to (1) access and retrieve information from the text, (2) integrate and interpret what is read, (3) reflect and evaluate the text and relate it to the experience students (Curriculum, 2013).

To comply with NSC, students faced difficulties because they had low RCAIT. Their low RCAIToccured because of many factors contributing to this. One of them is teacher poor competence in designing learning task that must be implemented when students perform reading comprehension. Teachers' poor competence is worrying in relation to students' low RCAIT and it should be overcome immediately to avoid bigger proble concerning student' low RCAIT.

There is a need on the part of the teachers to be able to perform appropriately learning tasks design (LTD) that are given by the teacher at the beginning, middle and the end of learning process. LTD in reading class circumstance will be more effective if it promotes active learning. This is in line with the explanation from Meyers \& Jones (1993) that states "Active learning involves providing opportunities for students to meaningfully talk and listen, write, read, and reflect on the content, ideas, issues, and concern of an academic subject". This opinion implies that active learning offers paradigm shift in teaching and learning activities between teacher and students. This is to say that teacher is no longer the source of learning. On the other hand students play the centre role to engage and be active in their learning process. Applying LTD that refers to active learning and modeling by teachers, students do not play traditional roles as 
passive receptors in which students are required to learn and practice how to capture knowledge and skills so as to be able to use them meaningfully.

Based on the above problem concerning students' low RCAIT, there is a need to seek possible solution to overcome the problem in learning activities. In an effort to overcome students' problem in RCAIT of the 5th grade of elementary school, this study applied the interactive compensatory model (ICM) for LTD that was considered relevant and effective to improve RCAIT of 5th grade elementary school in Bandung regency.

\section{LITERATURE REVIEW}

Yochum (1991), Fox (2009), Sahin (2013), Croce (2014), Walters (2014) in their research respectively found that some primary school children had difficulty in RCAIT. Their study found that there were many factors contributing to the problem. In line with their findings, similar difficulties were experienced by 5 th grade elementary school student in Indonesia. This condition is supported by the data released by PISA. The report reveals the average score of Indonesian students' reading ability were still below the OECD country average. Their reading comprehension ability was weak because they were incompetence in: understanding paragraph ideas, reading graphs, understanding relationships between facts, understanding relations of linguistic logic, and finding main ideas (OECD, 2016). In the same vein, a report released by PIRLS (2015) revealed students' reading ability of fourth grade school children whose average age was 9.5. Their average score of reading achievement was 397 and placed Indonesia in the ninth position among the low achieving countries.

\section{Reading Comprehension}

Reading comprehension is at the core of the reading activities. it has several stages namely background knowledge or schematics, literal understanding, higher level comprehension, and the ability to learn from the text. Its stages for sure are interrelated (Jennings, Caldwell \& Lerner, 2006). It actively requires meaning acquisition performed by the reader in relating the initial knowledge and experience associated with the content of the reading. It takes into consideration three main points namely: previous knowledge and experience associated with the text, the connection between the previous knowledge possessed by the reader and the text to be read, and the process of meaning making in accordance with the views the readers possess. This is to say that reading comprehension relies heavily on readers' understanding on basic cognitive knowledge, prior knowledge, vocabulary commands, conceptual knowledge, and language knowledge (Hamra\&Syatriana, 2012).

\section{Informational Text Features}

Informational text refers to text conveying information and explaining ideas (Jennings, Caldwell \& Lerner, 2006). For the purposes of this study, It is used with the content of science. It has various features as follows:

1) The order or time sequence is often used to present events such as the War of France and India (in history class). It can also be used to deliver cell division (in biology class). Keywords frequently used for sequence structure include first, second, third, then, then, finally.

2) A list of description is used to describe the features of an object or event.

3) Comparing and contrasting are used to decribe similarities and differences between two objects. This feature can be used in a study of social texts and the science of texts. The keywords include the same, similar to, the same as, resembling, compared to, like, different from, yet, and yet.

4) Causal pattern is applied to describe the reason for a particular event. The keyword used are: if, so, so, because, as a result of, for, therefore, cause and effect.

5) Problem-solution organizational patterns is used to discuss problems and suggests possible solutions on the topic given (Jennings, Caldwell \& Lerner, 2006).

Why applying Interactive Compensatory Model (ICM)?

Some studies related to ICM were conducted by Stanovich (1980, 1984), Simpson (1983), Perfetti (2010), McNeil (2012), Amiryousefi, Scrhraw \& Brooks (2014), Ismail, Li (2015), Tracey (2017). Their findings revealed that in order to improve students' reading comprehension ability, one of the most effective strategies was the ICM. Based on their findings, it was found that during and after the learning process, most students in the experimental group had better achievement in reading comprehension, enthusiasm, active learning, and enjoyment when reading text using the ICM. Their reading comprehension achievement was better when viewed based on comparison between higher posttest scores and lower pretest scores. From their findings it can be concluded that there was a significant difference in the students' achievement of reading comprehension between students who learned by using ICM and students who did not.

\section{Learning Task Design (LTD)}

Teachers should design learning task based on conceptual analysis. They should stimulate students with provoking questions that are appropriate to their thinking skills. They should provide an effective strategy to facilitate students in learning particularly for reading comprehension activity. It is expected that their effective strategy enables students to both realize what they have understood and apply their reading comprehension effectively. Students' achievement is undoubtedly inseparable from their metacognitive control. This is to say that the their involvement in the process of reading and writing process will be under the control of their metacognitive domain (Flavel, 1998; Puspita \& Yudiantara, 2017). 
LTD is developed by referring to the model of the Integrated Thematic Implementation Plan of the 2013 national curriculum for Indonesian elementary school. It should be noted from the beginning that determination of core competencies, basic competencies, indicators and learning objectives refer to the syllabus development (Puspita, 2017). In the learning steps, learning task refers to the steps of lesson plan of the Curriculum 2013. Its scientific steps are replaced by the learning steps offered by the ICM and these replacements do not change the scientific meaning of the learning process.

In observation step, learning task refers to the activities of the students including: listening to the teacher reading text on the story and observing story related images. Problem formulation step refers to students' activities include: filling out the student worksheet to write down both what they know and they do not concerning the text itself and activating their initial knowledge in relation to the text. Collection data step refers to students' activities consisting: reading text or performing direct activities. Data analysis step refers to students' activities in answering description questions about the text and writing discussion reports. Communication step has something to do with students' activities in presenting both their results of discussion and field activities.

\section{METHODOLOGY}

The study applied quasi-experimental method by implementing Non-equivalent Groups Design (NEGD). It used Pretest-Postest design with control group. There were 6 classes serving as experimental class $(\mathrm{N}=68)$ and 3 classes acting as control class $(\mathrm{N}=68)$. This research was conducted in elementary schools located in Bandung regency. Population in this study were 5th grade of elementary school with their average age from 10 to 11 years old. Samples were taken at a random basis with easy access to information was taken into consideration.

\section{A. Participants}

The samples of this study were eight classes of 5th grade taken from the following schools: Cingcin 01 State Elementary School (1), Cingcin 02 State Elementary School (2), Islamic elementary school of Nurriyadh (3). In a nutshell, 136 students and 8 teachers participated in this study.

\section{B. Data Collection}

This study collected and analyzed learning conditions of 5th grade reading comprehension achievement of primary school in Bandung regency by deploying interviews and observation. To achieve the objective of the study, It collected data on the effectiveness of the use of instructional design based on Interactive-Compensatory model developed through pretest and posttest analyzed through quantitative t-test formula.

\section{Data Analysis}

Data analysis was performed to determine the mean of standard deviation scores on pre-test and post-tests. Normality tests and homogeneity were applied to show that two or more groups of sample data were similar in their variance. In the regression analysis, the required analytical requirement is that the regression error for each group is based on the dependent variable having the same variance. Homogeneity test was done by comparing the largest variance and the smallest variance by using table. To see students' improvements in RCAIT before the experiment and after the experiment in the control class and the experimental class was calculated using a normalized gain with the level category if $g>0.7$, then the significant level of gain is expressed in the high category, if 0.03 Untuk $g \leq 0.7$ then the gain level is expressed in the medium category and if $\mathrm{g}<0.3$ then the gain level is in the low category. In processing, instrument testing, proving the level of validity and reliability of a measuring instrument or data analysis is the normality and homogeneity test data, also test the difference of two average processed using SPSS version 16.

\section{RESULT AND DiSCUSSION}

This study was aimed at investigating the effectiveness of ICM using LTD applied in learning task to improve students' RCAIT. It gathered several findings which were organized and described in the following section. The result of students' RCAIT after learning using LTD based on ICM with t-test can be seen in the table below.

TABLE 1

DIFFERENCE TEST ON RCAIT BETWEEN EXPERIMENTAL AND CONTROL CLASSES
\begin{tabular}{|l|l|l|l|l|}
\hline Data & $\boldsymbol{t}_{\text {hitung }}$ & $\boldsymbol{d} \boldsymbol{f}$ & $\boldsymbol{t}_{\text {tabel }}$ & Sig. \\
\hline posttest_control 1 & 6,825 & 44 & 1,050 & 0,000 \\
\hline posttest_control 2 & 5,260 & 42 & 1 & 0,000 \\
\hline posttest_control3 & 5,641 & 44 & 1,050 & 0,000 \\
\hline
\end{tabular}

Based on Table 1, it is shown that the mean difference test to the RCAIT of the experimental class and control class at the 0.05 significance level was obtained $\mathrm{p}$ (sig.2-tailed) $=0,000$. This means that RCAIT between the experimental class students and the control class was different. Any difference in the average gain of RCAIT in the experimental class with the gain of thier counterpart will be explained in table 2 below. 
TABLE 2

AVERAGE PERCENTAge OF StUdents' RCAIT BEFORE AND AFTER THEy PERFORMEd LTD BASED ON ICM

\begin{tabular}{|c|c|c|c|c|c|c|c|}
\hline \multirow[t]{2}{*}{ Item No } & \multirow[t]{2}{*}{ Indicator } & \multicolumn{3}{|c|}{ Experiment class (\%) } & \multicolumn{3}{|c|}{ Control class (\%) } \\
\hline & & (1) & (2) & (3) & (1) & $(2)$ & (3) \\
\hline 1 & $\begin{array}{l}\text { Understanding the meaning of words that are appropriate } \\
\text { for use in the text }\end{array}$ & 32,1 & 24 & 28,2 & 3 & 2,8 & 3 \\
\hline 2 & $\begin{array}{l}\text { Recognizing the relationship between paragraphs in the } \\
\text { text }\end{array}$ & 26,2 & 22 & 11,7 & 2 & 6,7 & 4 \\
\hline 3 & Expressing main idea & 27,4 & 22 & 19,1 & 7 & 5,7 & 5 \\
\hline 4 & $\begin{array}{l}\text { Answering questions that required explicit answer from } \\
\text { text }\end{array}$ & 26,2 & 21 & 29,4 & 6 & 2,8 & 8 \\
\hline 5 & Mentioning keywords & 32,1 & 27 & 20,5 & 4 & 4,8 & 7 \\
\hline 6 & Recalling the content of the text using their own words & 26,2 & 18 & 11,7 & 5 & 5 & 4 \\
\hline 7 & Inferring from the text & 29,8 & 21 & 14,7 & 5 & 5,7 & 5 \\
\hline 8 & Distinguishing fact from opinion & 37,6 & 31 & 19,1 & 6 & 5,7 & 4 \\
\hline 9 & Mapping the content of the text & 13,1 & 25 & 27,9 & 7 & 5,8 & 8 \\
\hline 10 & Understanding author message & 37 & 26 & 19,1 & 6 & 4,8 & 7 \\
\hline 11 & Understanding text message & 13,1 & 13 & 23,5 & 0 & 0 & 4 \\
\hline
\end{tabular}

The table above illustrates that there is a considerable increase in the students' RCAIT of the experimental class when compared with the increase in RCAIT of the students in the control class with the highest average being 44 . In the experimental class, 1, 2 and 3 the highest average increases is on the first indicator of the ability to understand the meaning of the word in accordance with the use in the text. The lowest average increase is in the second indicator of identifying the relationships between parts of the paragraph in the text. While in the control class the average of the highest increase in the third indicator is to reveal the main idea. The implementation of LTD for reading comprehension based on ICM to improve students' RCAIT was done with the following steps. In the initial activity the teacher greeted and invited all students to pray according to their religion and belief respectively. The teacher checked learning readiness by filling out student attendance sheet and checking the students' clothes, positions and seating prior to the learning activities.

The teachers began activity by communicating to the student the planed activities to be performed. They delivered introductory story on the "Human Body Organ Function" text to stimulate students to share their personal experiences with the text "Human Body Organ Function" by asking students brainstorming questions about parts of the human organs and their functions. In order for students to understand the texts they were about to read, they were invited to engage in a learning activity that could invite students to relate their experiences to the content in the text. This was done with the expectation that if students activated prior knowledge earlier in the reading activity then they would no longer depend on the vocabulary difficulties available in the text.

One strategy that aimed to activate students knowledge was through brainstorming activities. It refers to a learning activity that is used at the beginning of learning activities. It is a learning technique used to gather ideas and opinions to answer specific questions, by putting opinions or ideas as much as possible. In line with this, Wallace (1992) says that one of the most popular early reading techniques used was brainstorming. It has several advantages as one of the classroom learning techniques, first, it does not require much preparation; second, it allows students to freely expend their initial knowledge and ideas to integrate with the theme to be learned on that day and all three brainstorming activities involve all students in learning activities.

Besides brainstorming, other activity was semantic mapping which aimed to classify all information produced by students. Then It was followed by vocabulary analysis. This stage required students to gather the information in the analysis activities by classifying information. In the stage of vocabulary analysis, the teacher explained to the students about all aspects of language. These linguistic explanation covered student's idea like, verb type, time form and pronunciation.

The next step was to write down the experiences students expressed on the board. They rewrote their experiences related to the functioning of human organs by filling in the Student Worksheet for column 1 with teacher guidance. They observed images of human organs displayed in the class. This image was a stimulus for students to know every part of their body. After observing image, they wrote their observation questions on the Student Worksheet in column 2 with teacher guidance. The things that were expected from the initial activities were student interest in the topic of learning, meticulous and careful attitude in making observations, as well as skills in writing information from observations and personal experiences.

In the core activities, students were assigned to read the text "Function of Human Body Organs". They read the text at a glance to look and search for important information that was searching for keywords and main ideas contained in the reading text carefully and thoroughly. Furthermore the teachers assigned students to dig information by reading quickly in order to seek important information from each paragraph by distinguishing facts and opinions of each paragraph of the text "Function of the Human Body Organs" and separating the information from each paragraph. They recalled important information from the text "Function of the Human Body Organs" by filling in the Student Worksheet in column 3 with teacher guidance. They also wrote questions related to the text "Function of Human Body Organs" on the Student Worksheet in column 3 with teacher guidance (Puspita \& Yudiantara, 2017). The expected outcomes of the core activities were the students' knowledge on the human organs and their functions, their ability to read 
comprehension in searching for information, and their ability to read comprehension in digging information from the text. These expected outcomes indicated that they performed and play a role as independent readers.

In the final activity, the teachers concluded the learning outcomes by re-explaining the discussion results related to the text "Human Body Organ Function". They provided reinforcement to students on how to maintain students' organ health. They provided reinforcement to students to be diligent in reading and were not just satisfied with just reading one text of information. Furthermore, they gave the task to be done at home to students by way of making a report related to how to maintain a healthy body and how to maintain the health of the home environment. They closed learning activities by praying and greeting. The expected outcome of closing activities was that students were motivated to diligently read informational texts related to any topic so that they had extensive knowledge.

To implement LTD based on ICM successfully, the teachers should be able to facilitate the students to actively construct their knowledge. They must have special learning techniques that can make students become active and independent readers. They can achieve this by realizing an active, creative and fun learning process. The learning process will cause learners to think uniquely, analyze, solve problems when it comes to making decisions (Iskandarwassid \& Sunendar, 2011)

The implementation of this learning illustrates in general that the process of reading comprehension learning was done by systematic steps in order to be able to achieve the learning objectives. The results obtained from the limited trials and extensive trials show that there was a difference in RCAIT of 5th grade students of primary school before and after the introduction of learning using LTDs based on ICM. This was evidenced by the t-test results on the gain gain $\mathrm{p}$ (sig. (2-tailed) $=0,000$ This means there was a significant increase. The resulting improvement varies depending on some very important factors. First, the teacher's ability to stimulate and convey information in learning so that the information became meaningful for the students. Second, the ease of access to information which implied that there was the availability of textbooks and supporting books for students provided at school. Third, parental guidance in providing literacy artifacts at home (Mustafa, 2014). Fourth, the basic knowledge that students have concerning the content of the text they read.

\section{Implications}

LTD based on ICM contributed to RCAIT improvement. It has implications on the convenience of teachers in achieving learning objectives with the support of interesting learning media, practical teaching materials, student worksheet and activities that can stimulate students to think critically. It can be applied to support literacy improvement, reorganization, inferential and evaluative level and it also promotes student to be able to apply their reading comprehension in their real life. It can be adapted to various environments either with easy access or difficult access to environment information. In addition it offers teachers ease to implement in the learning process and is flexible in any semester to improve students' RCAIT.

\section{REFERENCES}

[1] Amiryousefi, Mohammad. (2014). Interactive-Compensatory Model of ESP Reading Comprehension: Vocabulary Knowledge, Reading Comprehension and Reading Strategies in Focus. The Iranian EFL Journal, 10. 5, 1-10.

[2] Croce, Anne Keri. (2014). Assessment of Burmese Refugee Students' Meaning Making of Scientific Informational Texts. Journal of Early Childhood Literacy, 14.3, 389-424.

[3] Curriculum. (2013). Elementary School: Basic Competencies. Jakarta: Departement of Education and Culture.

[4] Fox, Emily. (2009). The Role of Reader Characteristics in Processing and Learning From Informational Text. Review of Educational Research Spring, 79. 1, 197-261.

[5] Flavell, J. H. (1987). Speculations about the Nature and Development of Metacognition. In F. E. Weinert \& R. H. Kluwe (Eds.), Metacognition, Motivation and Understanding. Hillside, New Jersey: Lawrence Erlbaum Associates, 21-29.

[6] Hamra, Arifuddin, Syatriana, Eny. (2012). A Model of Teaching for University EFL Reading Student: Analysis and Model Design. English Language Teaching, 5.10, 1-11.

[7] Ismail, Li, Shaik Abdul Malik, Petras, et.all. (2015). Compenstory Reading among ESL Learners: A Reading Strategi Heuristic. English Language Teaching, 8. 8, 46-55.

[8] Iskandarwassid\&Sunendar, Dadang. (2011). Strategi Pembelajaran Bahasa. Bandung: Remaja Rosdakarya.

[9] Jennings, Caldwell \& Lerner. (2006). Reading Problems, Assesment and Teaching Strategies. Boston: Pearson.

[10] McNeil, John D. (1992). Reading Comprehension. New York: Harpen Collins Publishers 3rd Edition.

[11] Meyer, Chet\&Jones, Thomas B., (1993). Promoting Active Learning: Strategies for Collage Classroom 1st Edition. Maxwell Macmillan International PublisH1ng Group: New York.

[12] Musthafa, Bachrudin. (2014). Literasi Dini dan Literasi Remaja : Teori, Konsep dan Praktik. Bandung : CREST.

[13] Perfetti, Charles A. (2010). Representations and Awareness in the Acquisition of Reading Competence Learning to Read: Basic Research and Its Implications. New York: Routledge.

[14] PIRLS. (2015). Assessment Framework 2nd Edition. International Study Center.

[15] OECD. (2016). PISA 2015 Assesment and Analytical Framework: Science, Reading, Mathematic, and Financial Literacy. Paris: PISA, OECD Publishing.

[16] Puspita, Ryan Dwi. (2017). Pengembangan Perangkat Pembelajaran Tematik Terpadu Berbasis Model Interactive Compensatory untuk Meningkatkan Kemampuan Membaca Pemahaman Teks Informasi. Bandung: UPI.

[17] Puspita, Ryan Dwi, Sunendar, Dadang, Musthafa, Bachrudin, Yudiantara, Rully Agung. (2017). The Use Of InteractiveCompensatory Model Based-Learning Material To Improve Informational Text Reading Comprehension Ability Of 5th Grader Elementary School In Bandung Regency,Indonesia. Advance Science Letters, 23. 11, 10952-10954. 
[18] Puspita, Ryan Dwi, Yudiantara, Rully Agung. (2017). KWL Worksheet-Based Integrated Thematic Learning To Improve Informational Text Reading Comprehension Of 5th Grade In Bandung Regency. Golden Age, 1. 1, 67-75.

[19] Sahin, Ayfer. (2013). The Effect of Text Types on Reading Comprehension. Mevlana International Journal of Education, 3.2, 57-67.

[20] Scraw, Gregory, Brooks, David. (2014). Using Interactive, Compensatory Model of Learning to Improv Chemistry Teaching. Journal of Chemical Education, 84.4, 637-640.

[21] Simpson, Lorsbach \& WhiteHouse. (1983). Encoding nd Contextual Components of Word Recognition in Good and Poor Readers. Journal of Experimental Child Psychology. 35, 161-171.

[22] Stanovich, Keith E. (1980). Toward and Interactive-Compensatory Model of Individual Differences in The Development of Reading Fluency. Reading Reaserach Quartely, 16.1, 32-71.

[23] Stanovich, Keith E. (1984). The Interactive-Compensatory Model of Reading A Confluence of Developmental Psychology. Remedial and Special Education, 5.3, 11-19.

[24] Tracey, Diane H., Morrow, Lesley Mandel. (2017). Lenses on Reading An Introduction to Theories and Models. (Third Edition). New York: The Guilford Press.

[25] Wallace, Catherin. (1992). Reading. Oxford: Oxford University Press.

[26] Walters, Braker, Barbara A. (2014). Informational Text and the Common Core: A Content Analysis of Three Basal Reading Programs. SAGE Open, 4.4, 1-8.

[27] Yochum, Nina. (1991). Children's Learning From Informational Text: The Relationship between Prior Knowledge and Text Structure. Journal of Literacy Research, 23.1, 87-108.

Tri Indri Hardini is a permanent lecturer in Universitas pendidikan Indonesia. She belongs to french education department. She is currently seving as vice dean for academic affair in Faculty of Language. There are many activities concerning french language teaching that she has participated and one of them is seving as vice chairperson in an organization APFI PPSI. Her intelectual contribution is devoted mainly as a reviewer for curriculum development in french language teaching. She has published some scientific articles which was published on FRANCISOLA: Revue indonésienne de la langue et la littérature françaises (e-ISSN: 2527-5100 | p-ISSN: 2527-5097) Vol 2, No 2 (2017) on A Study Of Women's Language Varieties nn French Movie. Other articles was published in Jurnal TAWARIKH Vol 8, No 2 (2017) on 27 countries, 23 languages: Communication Challenges in The European Union, a Comparison with ASEAN Economic Community; etc.

Ryan Dwi Puspita is a Doctor in Elementary education majoring in Language teaching from Universitas Penddikan Indonesia in 2017. She belongs to STKIP Sebelas April as full time lecturer in Elementary school Education department. Her research interest includes reading comprehension, initial writing, learning tool development, and language role in traditional game. She has published some scientific articles which was published on accredited international journals, Advanced Sciencie Letters on The Use Of Interactive-Compensatory Model Based-Learning Material To Improve Informational Text Reading Comprehension Ability Of 5th Grader Elementary School In Bandung Regency,Indonesia. Other article was published in Jurnal Pendididikan dan Humaniora, entitled "Improving Students Reading Comprehension Ability Through Integrated Thematic Learning with School Literacy Movement Support. In national jurnal of Golden Age, she published the article entitled KWL Worksheet-Based Integrated Thematic Learning To Improve Informational Text Reading Comprehension Of 5th Grade In Bandung Regency.

Rully Agung Yudhiantara was born in Bandung, Indonesia on November 22, 1979. He accomplished his Master in English Education program, Universitas Pendidikan Indonesia, Bandung, Indonesia, in 2009. He is currently a permanent lecturer in UIN Sunan Gunung Djati Bandung, Faculty of Tarbiyah and Keguruan, English Education Program. He has published several articles: The Use Of Interactive-Compensatory Model Based-Learning Material To Improve Informational Text Reading Comprehension Ability Of 5th Grader Elementary School In Bandung Regency,Indonesia. Other artice in national journal, Jurnal Pendididikan dan Humaniora, entitled Improving Students Reading Comprehension Ability Through Integrated Thematic Learning with School Literacy Movement Support. In other journal, Golden Age, he published article entitled KWL Worksheet-Based Integrated Thematic Learning To Improve Informational Text Reading Comprehension Of 5th Grade In Bandung Regency; etc.

His research interest including: Language Teaching, Reading Comprehension and Mobile Assisted Language learning 